\title{
Isolation of Ascomycetous Fungi from a Tertiary Institution Campus Soil
}

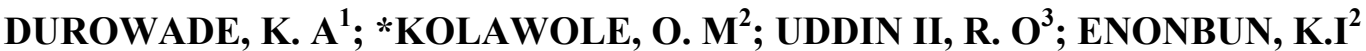

${ }^{l}$ Department of Epidemiology and Community Medicine, College of Medicine, University of Ilorin. Kwara State. ${ }^{2}$ Department of Microbiology, Faculty of Science. University of Ilorin. P.M.B 1515, Ilorin, Kwara State. Tel: 08060088495. Email: tomak74@yahoo.com ${ }^{3}$ Department of Crop Protection, Faculty of Agriculture, University of Ilorin. Kwara State

\begin{abstract}
Studies were carried out on the ascomycetous fungi present in six different but carefully selected sites on the University of Ilorin permanent site soil. Fungi isolation was done by the soil dilution method incubated at $27^{\circ} \mathrm{C}$ for 72 hours. The predominant Ascomycetous fungi isolated include among others; Aspergillus niger, Fusarium solani, Fusarium oxysporum, Penicillium italicum, Fusarium acuminatum, Fusarium culmorum, Candida albicans, Botrytis cinerea, Geotrichum candidum, Trichoderma viride, Verticillium lateritum, Curvularia palescens, Penicillium griseofulvum, Penicillium janthinellum, Penicillium chrysogenum, Aspergillus terreus, Aspergillus flavus, Aspergillus fumigatus, Aspergillus glaucus, Aspergillus clavatus, Cladosporium resinae, Alternaria alternate, Trichothecium roseum, Phialophora fastigiata, Aspergillus nidulans, Aspergillus wentii, Humicola grisea, Trichophyton rubrum, Helminthosporium cynodontis, Penicillium funiculosum, Penicillium purpurogenum, Saccharomyces cerevisiae, Trichoderma harzianum, Scopulariopsis candida.The physicochemical characteristics of soil samples was found to affect the distribution and population of fungi. The colony count in the study are ranged between $5.8 \times 10$ " per gram of soil to $1.63 \times 10^{\prime \prime}$ per gram of soil. The soil consists of high organic matter content. @ JASEM
\end{abstract}

Soil contains a vast array of microorganisms such as bacteria, viruses, fungi, actinomycetes, protozoa and algae (Alexander, 1977; Olowonihi, 2003). Soil organism participates in the genesis of the habitat, which they live. They, together with the total biota and especially the higher vegetation, constitute one of the five interactive factors in soil formation; the other four are climate, topography, parent material, and time (Beare, 1997). The physical and chemical breakdown of rocks to fine particles with large surface areas and the accompanying release of plant materials initiate the soil forming process (Paul and Clerk, 1996). Two major nutrients that are deficient in the early stages of the process are carbon and nitrogen therefore, the initial colonizer of soil parent material are often organisms capable of enhancing photosynthesis and nitrogen fixation. These are predominantly the cyanobacteria, also known as the blue green algae (Sylvia et al., 1997). After higher vegetation has become established, a continuum of soil processes produces the dynamic mixture of living and dead cells, soil organic matter (SOM), and mineral particles in sufficiently small sizes to permit the intimate colloidal interaction characteristic of soil (Lambart et al., 1979; Andrew et al., 2008). The Ascomycetes (Sub-division Ascomycotina) constitute the largest class of fungi, the number of known species being approximately 32,000 . There is considerable diversity of form and structure among the Ascomycetes. At one end of the scale are the truffles and morels (Adamas et ai., 1999). The Ascomycetes derive their name from the ascus, the sac-like vessel which contains the sexual spores (ascospores).The ascus is a walled receptacle enclosing the spores and usually rupturing at the physical and nutritional factors where a pronounced affect on sporulation of fungi occur.Temperature, light, hydrogen ion concentration, aeration and humidity are some of the important physical factors. Factors such as source of Carbon, Nitrogen, Vitamins and trace elements also determine the rate of spore development under natural (soil) conditions (Michael and Donald, 1996; Ivan et al., 2008). It has been discovered that micro-organisms play an important role in the fertility of the soil, their abundance and existence is solely hung on the environmental (soil) conditions (Paul and Clerk, 1989). This study intends to examine the physicochemical characteristic of the soil samples and to identify as many Ascomycetors fungi as possible present in the six different sites of soil collected from the University of Ilorin permanent site.

\section{MATERIALS AND METHODS}

Study Area: This study was carried out in the permanent site of the University of Ilorin $\left(8^{0} 29 \mathrm{~N}\right.$, $\left.4^{0} 35 \mathrm{E}\right)$.Ilorin is on southern guinea savanna ecological zone in Nigeria. Between the months of February to November rainfall distribution pattern of the land is bimodal; with the first major peak between May and mid-August while the second peak is between September and the mid-November. The average rainfall for Ilorin is 1000-1240

Selection of sample sites: Suitable sites were selected within the study area. Six sites were chosen they includes:

Site 1; Academic Area:

This is the area around the lecture halls, administrative buildings etc.There is constant movement of students and academic staff in this area. It is often littered with paper wastes from food eaten by students.

\section{Site 2: Clinic:}

This is the area around the school Health centre where staff and students get their medical attention. Site 3: Primary School (University of Ilorin Staff School):

This is the study environment of the primary school pupils. It is often characterized with the movement 
of children and it is often littered with paper and food remains of the children.

Site 4: Senior Staff housing:

This is the residential area of the senior staff of the university. The area is characterized with children playing in their courtyard. It is often littered with domestic waste, used papers, dead leaves and grasses.

Site 5: Reservoir:

This is the area around the water storage system in the University. There is a constant movement of water tankers and staff in the area. It is often littered with dead leaves and grasses and food remains of the people coming into the area.

Site 6: Student housing:

This area covers the halls of residents of the University students. It is characterized with the to and fro movement of the students in the halls. It is often littered with used papers, dead leaves from trees and domestic wastes.

Collection of soil samples: Soil samples were collected employing sterile soil augers, hand trowel and polythene bags (Akinyanju and Fadayomi, 1989). The soil was dug out using augers up to 0$20 \mathrm{~cm}$ depth and was immediately scooped into sterile polythene bags using the hand trowel. The samples were collected from 2 spots in each site and then mixed together in order to obtain a representative sample.

\section{PHYSICO-CHEMICAL ANALYSIS}

Soil Water Holding Capacity Determination: Soil sample which has been dried in the oven at $105^{\circ} \mathrm{C}$ for 24 hours was used for the water holding capacity determination according to the method of Pramer and Schmidt (1964).

Soil Moisture Content Determination: The method used for this determination was that of Pramer and Schmidt (1964).

$\%$ organic matter (humus) in sample $=$ $\frac{\text { weight of humus }}{\text { Weight of dry soil taken }} \times 100$

Soil pH Determination: About $20 \mathrm{~g}$ of air-dried sieved soil into a $100 \mathrm{ml}$ beaker and $20 \mathrm{ml}$ of sterile distilled water was added. The suspension was left to stand for 30 minutes with occasional stirring to enhance equilibrium reaction. The $\mathrm{pH}$ of the suspension was taken by inserting the glass hydrogen $\left(\mathrm{H}^{+}\right)$electrode of the $\mathrm{pH}$ meter (Pye Unicam, model $292 \mathrm{mk}^{2} \mathrm{pH}$ meter) into the partly settled suspension.

Preparation of Media: Two media were employed in this work. They are Modified Nutrient Agar (MNA) and Potato Dextrose Agar (PDA)

Isolation using Soil Dilution Method: Serial dilution of the experimental soil sample up to $10^{-4}$ dilution using sterile distilled water was carried out. To enhance fungal isolation, sterile pipette were used to remove $1 \mathrm{ml}$ of each dilution and introduced into the surface of the agar medium.
Plates were then incubated for 72 hours at room temperature $\left(27^{\circ} \mathrm{c}\right)$ for fungal growth.

Preparation of Stock Culture of Fungal Isolates: The pure cultures of the different isolates obtained were sub-cultured into sterile McCartney bottles containing agar slant. These bottles were also incubated at $27^{\circ} \mathrm{C}$ until appreciable mycelia growth and fungal sporulation were observed.These were kept as stock cultures.

Characterization and Identification of Ascomycetous fungal Isolates: Colonial morphology and microscopic examinations of the various isolates of pure cultures were used to determine the reproductive and vegetative structures. Consequently, identification was done using Onions et al., (1981). Spore identification was achieved by reference to Spore atlases of Gregory (1973) and Anna (1990).

\section{RESULTS AND DISCUSSION}

The results based on the physico-chemical characteristics of the soil samples viz: water holding capacities, moisture contents, organic matter contents, and $\mathrm{pH}$ values is shown in Table 1. The results revealed that site 3 had the highest water holding capacity of $0.43 \mathrm{ml} / \mathrm{g}$, while site 2 had the lowest with $0.3 \mathrm{ml} / \mathrm{g}$. The range value was $0.13 \mathrm{ml} / \mathrm{g}$. This finding could possibly be correlated to the sandy content in the soil sample from site 2 and the clay content in the soil sample in site 3 . Site 4 had the highest moisture content of $1.56 \%$, while the least value of moisture content obtained goes to site 2 with $0.12 \%$. In the case of organic matter contents, site 6 had the highest with $4.76 \%$ and the lowest value goes to site 5 with $2.63 \%$.

Based on the $\mathrm{pH}$ values of the sampled soil, it was found that site 4 was acidic with a $\mathrm{pH}$ value of 5.7 while site 1 recorded a high $\mathrm{pH}$ value of 7.4 indicating that the soil was alkaline. This range of $\mathrm{pH}$ values affected the type of fungi found in the different sites. The various ascomycetous fungi isolated in all the six sites were identified and are represented in Table 2. In all, thirty five (35) ascomycetous fungi were isolated.The results based on the different colony counts of each dilution values (i.e. $10^{-1}, 10^{-2}, 10^{-3}$ and $10^{-4}$ ) of each site is shown in Fig 1. The average number of colonies of each site based on the varying dilution was calculated and results showed that site 3 had the highest number of $5.8 \times 10^{\prime \prime}$ per gram of soil while site 5 recorded the lowest number of $1.63 \times 10^{\prime \prime}$ per gram of soil. The experimental evidence shown in this study indicates that there are a lots of ascomycetous fungi present in the different sites of the University of Ilorin (permanent site). No two environments are identical in terms of their fungal contents. However, there are basic groups of fungi encountered in this study which have been obtained by previous workers, in other parts of the world. Nelson, (1988) reported the occurrence of 
Trichoderma viride and Trichoderma album (both of which are ascomycetes) in Douglas-fir-soil.

In this study, the isolation of some fungi that are of public health significance known to cause allergies in certain sensitive people was of particular interest. According to Patterson (1972), the four most common allergic moulds are Alternaria,

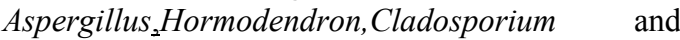
Penicillium based not only on incidence but on skin test reactivity. In this study, of all the isolates (Table 2). Aspergillus spp. (especially Aspergillus niger) was found to be frequently isolated. This could possibly be due to the fact that Aspergillus niger is a common contaminant on various substrates while others include Fusarium spp, Penicillium spp, Botrytis spp and Geotrichum spp. Their common occurrence could also be due to their high sporulating nature and this is also coupled with their ability to grow well on laboratory media (Oyeyiola and Hussein,1992). This finding is in consonance with the work done by Ekundayo, (2004)

The soil moisture has a direct effect on the population of fungi positively hence, at higher moisture, the tolerance and colonization by fungi is badly affected (Adams et al., 1999). Excessive moisture leads to inadequate oxygen diffusion.In the results shown in Table 1 and Figure 1, Site 3 has a relatively high moisture content and consequently the fungal plate counts was high. However, Site 4 had the highest moisture content of $1.56 \%$ but the fungal plate count was lower compared with Site 3 . This finding could possibly be correlated with moisture excessiveness leading to inadequate oxygen diffusion thereby affecting fungal colonization. Fungi as a group will tolerate a wide $\mathrm{pH}$ range, but some fungi are more tolerant to acidic soils. As compared to bacteria they can tolerate a wide range of $\mathrm{pH}$ 4-8 (Ketchum, 1988) which also correlates with the findings in this study as shown in Table 1 and Figure 2. As indicated in this study, site 3 which was acidic ( $\mathrm{pH}$ 6.1)has the highest fungal plate count. The high alkaline condition existing in sites 1,2 and 6 could possibly be responsible for the low occurrence of Penicillium spp. This finding is in consonance with the work done by Ketchum, (1988) who reported that any unfavourable alkaline soil often inhibit the development of Penicillium spp. The results presented in this study indicated that site 6 had the highest organic matter content of $4.76 \%$, hence has very high fungal counts on dilution plates. Adams et al., 1999 reported that humus (organic matter) rich soils have large fungal population than soil poor in humus. It can also be deduced from this study that the organic matter contents of the soil which is the main source of utilisable substrates for the fungi plays a significant role as high number of the fungal species were recovered from sites 3,4 and 6 . Though, site 5 is acidic, it has little organic matter content and this could possibly be responsible for its low fungal population.This finding is in consonance with the work done by Andrew et al., (2008). Candida albican isolated in this study is of medical importance. They are responsible for a lot of occular infections especially in patients whose immune status has been compromised by trauma, surgery and age.The isolation of Aspergillus fumigatus in this study is also of medical significance. They are known to produce Aflatoxin which is associated with the disease called Aspergillosis. Summarily, it is of interest to note that most of the ascomycetous fungi obtained in this study correlated with the physico-chemical characteristics of the sites from where they were isolated.

In conclusion, the University of Ilorin (Permanent site) soil is good for planting and agricultural activities. Though heterotrophic bacteria and fungi associate with decompositions of organic matter and nitrogen fixation occur in the different soil sites, pathogenic micro-organisms also exist in high numbers in some of the sites.

Table 1: Physico-Chemical Characteristics of Experimental Soil Samples

\begin{tabular}{lllll}
\hline \multirow{2}{*}{ SITES } & $\begin{array}{l}\text { WATER HOLDING/ } \\
\text { CAPACITY (ml/.g) }\end{array}$ & MOISTURE CONTENT (\%) & $\begin{array}{l}\text { ORGANIC MATTER } \\
\text { CONTENT (\%) }\end{array}$ & $\mathrm{pH}$ \\
\hline 1 & 0.35 & 0.14 & 3.33 & 7.4 \\
2 & 0.30 & 0.12 & 3.79 & 7.3 \\
3 & 0.43 & 0.81 & 4.30 & 6.1 \\
4 & 0.39 & 1.56 & 4.05 & 5.7 \\
5 & 0.41 & 0.14 & 2.63 & 6.6 \\
\hline 6 & 0.42 & 0.52 & 4.76 & 7.2 \\
\hline
\end{tabular}


TABLE 2: Frequency of Occurrence of Ascomycetous Fungal Isolates from Sample Sites

\begin{tabular}{|c|c|c|c|c|c|c|c|c|}
\hline \multirow[t]{2}{*}{$\mathrm{S} / \mathrm{N}$} & \multirow[t]{2}{*}{ Fungi Isolates } & \multicolumn{6}{|c|}{ SITES } & \multirow[b]{2}{*}{$\%$ F.O } \\
\hline & & 1 & 2 & 3 & 4 & 5 & 6 & \\
\hline 1 & Aspergillus niger & + & + & + & + & + & - & 14.3 \\
\hline 2 & Fusarium solani & + & - & + & - & - & + & 8.5 \\
\hline 3 & Fusarium oxysporum & + & + & + & + & + & - & 14.2 \\
\hline 4 & Penicillium italicum & + & - & + & - & - & - & 5.7 \\
\hline 5 & Fusarium acuminatum & - & + & + & - & - & + & 8.5 \\
\hline 6 & Fusarium culmorum & + & + & + & - & + & + & 14.3 \\
\hline 7 & |Candida albicans & + & + & + & - & - & - & 8.5 \\
\hline 8 & Botrytis cinerea & - & + & - & + & + & + & 11.4 \\
\hline 9 & Geotichum candidum & + & - & + & + & + & - & 11.4 \\
\hline 10 & Trichoderma viride & - & + & + & + & - & - & 8.5 \\
\hline 11 & Verticillium lateritum & - & + & + & + & - & - & 8.5 \\
\hline 12 & Curvularia palescens & - & - & - & + & + & - & 5.7 \\
\hline 13 & Penicillium griseofulvum & + & - & + & + & - & + & 11.4 \\
\hline 14 & Penicillium janthinellum & - & - & - & + & - & + & 5.7 \\
\hline 15 & Penicillum chrysogenum & + & + & - & + & + & - & 11.4 \\
\hline 16 & Aspergillus terreus & - & + & + & + & - & - & 8.5 \\
\hline 17 & Aspergillus flavus & - & + & + & + & + & + & 14.3 \\
\hline 18 & Penicillum chermesianum & - & - & + & + & - & + & 8.5 \\
\hline 19 & Aspergillus fumigatus & - & + & + & + & - & - & 8.5 \\
\hline 20 & Aspergillus glaucus & + & + & - & + & - & + & 11.4 \\
\hline 21 & Aspergillus clavatus & + & + & + & - & - & + & 11.4 \\
\hline 22 & Cladosporium resinae & + & - & - & - & - & + & 5.7 \\
\hline 23 & Alternaria alternate & - & + & - & + & - & - & 5.7 \\
\hline 24 & Trichothecium roseum & - & + & + & - & - & + & 8.5 \\
\hline 25 & Phialophora fastigiata & - & - & + & - & - & + & 5.7 \\
\hline 26 & Aspergillus nidulans & - & + & - & + & - & - & 5.7 \\
\hline 27 & Aspergillus wentii & - & + & + & - & - & + & 8.5 \\
\hline 28 & Humicola grisea & - & + & + & - & - & + & 8.5 \\
\hline 29 & Trichophyton rubrum & - & + & - & - & - & - & 2.8 \\
\hline 30 & Helminthosporium cynodontis & - & - & + & + & - & + & 8.5 \\
\hline 31 & Penicillium funiculosum & - & + & + & - & - & + & 8.5 \\
\hline 32 & Penicillium purpurogenum & - & - & + & + & - & + & 8.5 \\
\hline 33 & Sacchoromyces cerevisiae & - & - & - & - & - & + & 2.8 \\
\hline 34 & Trichoderma harzianum & + & - & - & - & - & + & 5.7 \\
\hline 35 & Scopulariopsis candida & + & - & - & + & - & - & 5.7 \\
\hline $\mathrm{KEY}$ & & & & & & & & \\
\hline & $\begin{array}{l}\text { PRESENT (+) } \\
\text { ABSENT } \\
\% F . O=\text { Perce }\end{array}$ & & & & & & & \\
\hline
\end{tabular}

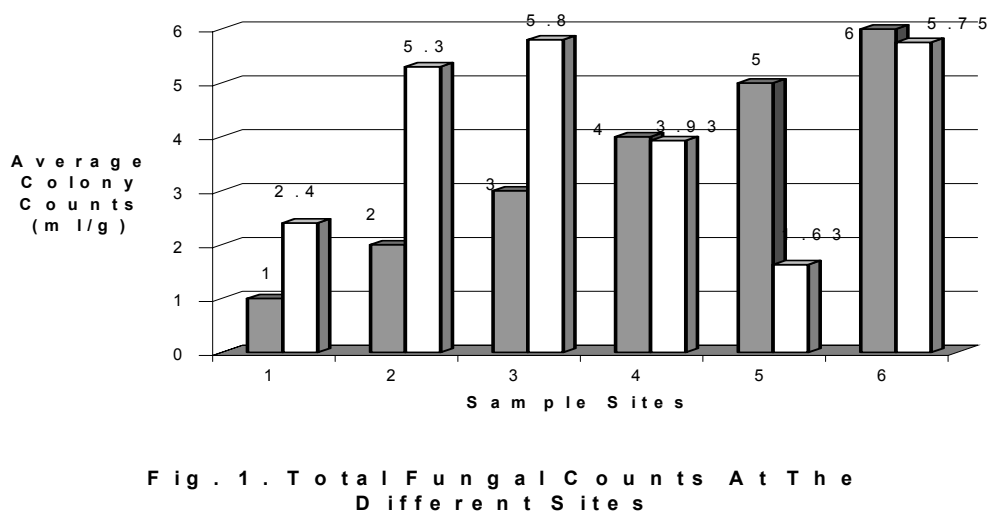

\section{REFERENCES}

Adams, C P; Bamford, K M; Early, M P. (1990): Principles of Horticulture ( $3^{\text {rd }}$ Ed.) Butterworth Heineman. Pp. 25

Akinyanju, J A; Fadayomi, O (1989). Effect of divron on Surgarcane Shizosphere Microbial population. Nigeria Journal of Botany 2: pp.49-58.
Andrew. W.C, James. M. T, Karen. H (2008). Do fungi have a role as soil stabilizers and remediators after forest fire?. Forest Ecology and Management. Volume 257.Issues 3, February.Pp 1063 - 1069 Elsevier

Anna, L S. (1990). A color Atlas of post-harvest diseases and disorders of fruits and vegetables. General Introductions and fruits Vol.78-79, pp.66-69

* Corresponding author: Durowade, $\mathrm{K} . \mathrm{A}^{1}$ 
Alexander, M (1977). Introduction to Soil Microbiology ( $2^{\text {nd }}$ Ed.) John Wiley \& Sons, New York. pp. 423-437.

Beare, M H (1997). Fungal \& Bacteria pathway of organic matter decomposition and Nitrogen and feneracana to soil ecology in sustainable agricultural system (Boca Raton Flamis cemis publishers) pp.67.

Ekundayo.E.O (2004). Fungi in the rhizosphere and non-rhizosphere soil of Okra cultivated in southern Nigeria. Nigerian Journal of Soil Science.14: 48 - 55 .

Gregory, P H (1973). Microbiology of the atmosphere ( $2^{\text {nd }}$ Ed.) Appendix I. Leonard Hill p.31.

Ivan. P.E, Rima. A.U, Donald. R. Z (2008). Isolation of Fungal cellobiohydrolase I Genes from sporocarps and forest soils by PCR. Applied and Environmental Microbiology, June Pp. 3481 - 3489.Vol. 74, No. 11 ASM

Ketchum, P A (1988). Microbiology concept and application. John Willey and Sons. New York pp.56.

Lambert, DH; Baker, D E ; Cole, H J (1979). The role of mycorrhizae in the interaction of plant with zinc, copper and other elements. Soil Sci. Sco. Amer, J. 43:976-980.

Michael, J S ; Donald, N M (1996). Soils. An introduction $\left(3^{\text {rd }}\right.$ Ed.) Prentice hall, upper saddle river New Jersey. pp. 150.
Nelson, E E (1988). Occurrence of Trichoderma in a Douglas fir soil - mycopathologia. pp. 280284.

Olowonihi, E T (2003). Studies on the distribution of Bacteria and Fungi in the five soil series of University of Ilorin Teaching and Research Farm. An M.Sc Thesis Dissertation submitted to the Department of Crop production, Faculty of Agriculture. University of Ilorin. Nigeria. November 2003 pp.6-18 (2)

Onion, A H S; Allsop, D; Eggins, H O W (1981). Smiths Introduction to Industrial Mycology ( $7^{\text {th }}$ Ed.) Edward-Arnold Publishers Ltd. London p.398

Oyeyiola, G P;Hussein H S N (1992). Fungi populations in the rhizosphere and rhizoplane of wheat grown in Kura Area of Kan, Northern Nigeria. Bioscience Research Communications 4(2): pp:129-133.

Patterson, R A (1972). Infestation of drytridiaceous fungi on phytoplankton in relation to certain environmental factors. Ecology 44 pp.416-429.

Paul E A ; Clark, F E (1996). Soil Microbiology and Biochemistry. $2^{\text {nd }}$ Edition. (New York; academic press pp. 225-229.

Pramer, D E; Schmidt, E L (1964). Experimental Soil Microbiology Burges publishing company Minneapolis, 15. Minnesota, USA.Sons Ltd. Beecles and London. pp.31-32.

Sylvia, D J.; Fufuman, P H; Zuberer, D (1997). Principles and applications of soil microbiology. (Upper saddle River W.J. Practice Hall) pp. 221-224. 